\title{
Engelli Bireylerin Meslek Seçiminde Etkili Olan Faktörlerin Incelenmesi $^{*}$
}

\author{
Examination of Factors That are Effective in Profession Choice of \\ Disabled Individuals
}

\author{
Muhammet Ü. ÖZTABAK ${ }^{* *}$
}

Öz

Engelli bireylere iş ve meslek kazandırmada yardımcı olmak, onları ekonomik açıdan bağımsız hale getirmek önemli amaçlardan biri sayılmaktadır. Fakat engelli bireylerin meslek seçimleri diğer bireylere göre daha zor bir süreçtir. Bu çalışmada 2015-2016 eğitim öğretim yllında farklı üniversitelerde okuyan veya mezun olmuş engelli bireylerin meslek seçimlerini etkileyen bazı faktörlerin incelenmesi amaçlanmıştır. Araştırmada, nitel araştırma yöntemlerinden "Olgubilim (fenomenoloji)" deseni kullanılmıştır. Çalışmada 10 engelli bireyle birebir görüşmeler yapılarak veriler toplanmıştır. Engelli bireylerin meslek seçimini etkilediği düşünülen, sosyal çevre etkisi, ekonomik düzey, annebaba tutumları, ilgi alanı, kampüsün fiziksel koşulları ve engel durumu değişkenleri incelenmiş ve katılımcılar tarafından sıralamaya konulmuştur. Buna göre engelli bireylerin meslek seçiminde en çok engel durumlarını, en az ise anne-baba tutumlarını dikkate aldıkları tespit edilmiştir.

Anahtar kelimeler: Engelli birey, meslek seçimi, mesleki rehberlik, üniversite öğrencisi

\begin{abstract}
Helping disabled people to gain a profession and place in working life as well as making them economically independent are considered as important goals. However, the choice of profession for disabled people is a more difficult process than the other individuals. In this study, it was aimed to investigate some factors that affect the profession choices of disabled individuals who studied in or were graduated from different universities during 2015-2016 academic years. In the study, "Phenomenological Research Design" was used as qualitative research method. The data of the
\end{abstract}

* Bu çalışma, 25. Ulusal Eğitim Bilimleri Kongresi’nde (21-24 Nisan 2016/Antalya) sözlü bildiri olarak sunulmuş ve geliştirilerek makale olarak hazırlanmıştır.

** Yrd. Doç. Dr., Fatih Sultan Mehmet Vakıf Üniversitesi, Eğitim Fakültesi, Eğitim Bilimleri Bölümü, muoztabak@fsm.edu.tr 
study were collected by interviewing with 10 disabled individuals. The variables which were thought to affect the choice of disabled persons -social environment influence, economic level, parental attitudes, area of interest, physical conditions of the campus and disability situation- were examined and put in order by participants. It has been found that in choosing a profession; disabled people take into consideration the most their disability situations and at least the attitudes of their parents.

Keywords: Disabled person, profession choice, vocational counselling, university student

\section{Giriş}

İnsanın geleceğini etkileyen en önemli kararlar arasında meslek seçimi bulunmaktadır. Meslek seçimi bir süreçtir ve bireyin yaşam tarzını ve kalitesini belirleyen kritik ve zor adımlardan birisidir. İnsanın hayatının büyük bir kısmını işinde geçirmesi, onun doğrudan mutluluğunu da etkileyen bir etken olarak karşımıza gelmektedir.

Bireyin yapabileceği meslekleri tüm yönleriyle değerlendirip, ihtiyaçları ve beklentilerini de göz önünde bulundurarak istenilen yönlerin ağır bastığı bir işe yönelmeye karar vermesi meslek seçimidir (Yeşilyaprak, 2013). Kuzgun’a (2011) göre bireyin tercih ettiği yani girmek istediği meslekler arasından birinde karar kılması ve buna hazırlanmak için çaba göstermesi meslek seçimi olarak adlandırılmaktadır. Seçim tercihten daha kapsamlıdır çünkü seçilen meslek aynı zamanda tercih edilen bir dizi meslekten biridir. Tercihlerin belirlenmesinde istekler rol oynar. Seçimde ise birey fiziksel ve zihinsel yeteneklerini, ekonomik durumunu, meslek eğitimini başarma olasıllı̆ını ve daha birçok faktörü göz önüne alarak kısaca erişme olasılığını hesap ederek, tercih listesindeki meslek seçeneklerinden birine karar vermiş olmaktadır (Kuzgun, 2011).

Böylesine önemli bir karar da genellikle lise yıllarında verilmektedir. Bu dönem aslında oldukça kritik bir dönemdir. Çünkü kişi yalnızca nasıl bir işte çalışacağını seçmemekte aynı zamanda seçeceği meslek ile hayat şartlarını da belirlemektedir. Böyle bir kararın lise dönemlerinde veriliyor olması aslında beraberinde riskler taşımaktadır. Çünkü seçeceği mesleğin sorumluluklarını yerine getirmediyse, olumlu ve mantıklı seçeneklerde bulunması, kararlar alması da epey güçleşmektedir. Meslek seçimi, meslek gelişimi içerisinde bulunan, meslekî gelişim sorumluluklarını başarıyla yerine getirme ve meslekî olgunluk seviyesi ile ilintilidir (Çoban, 2005).

Meslek seçimi, birçok faktörden etkilenen karmaşık bir süreçtir. Bireyin bu karar sürecinde etkilendiği bir dizi değer yargısı, ilgi ve inançları söz konusudur. Bireyin bu kararında mesleğe yönelik olarak duyduğu ilgi, sahip olduğu değerler ve elde edeceği tatmin gibi faktörlerin yanı sıra kişisel özelliklerinin de etkili olduğunu göstermektedir (Tokar, Fisher ve Subich, 1998). Bireyin yetenek, ilgi, değer ve isteklerine uygun bir meslekte çalışması fizyolojik gereksinimlerin yanı sıra psikolojik gereksinmelerine de doyum sağlar. Ancak çeşitli nedenlerle, kendisine uygun düşmeyen bir meslekte çalışmak zorunda kalmak, mesleki başarısızlığa, verimsizliğe neden olduğu gibi bireylerde psikolojik sorunlara da yol açabilir (Arsoy, 2010). 
Meslek seçimini etkileyen faktörler altı grupta toplanabilir (Super, 1957);

1. Biyolojik etmenler: bireyin fiziksel özellikleri, cinsiyet, beden yapısı, görme ve işitme durumu, vb.

2. Sosyolojik etmenler: duyguları, değerleri, aile ile ilişkileri, bağlı olduğu arkadaş çevresinin beklentileri ve baskıları, ailenin sosyal düzeyi, yakın ilişki kurulan öteki kişiler.

3. Psikolojik ya da kişisel etmenler: bireyin ihtiyaçları, duyguları, tutumları, değerleri, ilgileri, yetenekleri.

4. Ekonomik etmenler: ailenin ekonomik düzeyi, çevrenin ya da ülkenin genel ekonomik durumu, otomasyon ve teknik gelişmeler, bunların toplumun insan gücü ihtiyacı üzerindeki etkileri, vb.

5. Politik etmenler: mesleğe girme olanakları, iş bulma olanakları, değişik eğilim ve yetiştirme firsatlar1, vb.

6. Şansla ilgili etmenler: doğal afetler, işleri ve işyerlerini etkileyen beklenmedik olaylar, iç ve diş savaşlar, vb.

Engelli kişilerin, engelsiz kişilere oranla sosyo-ekonomik gelişmelerden (eğitim, sağlık, istihdam ve yoksulluk) ortalama daha negatif etkilendiği görülmektedir (World Bank, 2015). Aynı zamanda engelli çocuklar engelsiz çocuklara göre daha düşük okula başlama ve devam etme oranına sahiptirler (World Health Organization [WHO], 2011). Ettinger'e (1996) göre engelli bireyler, kariyer gelişimlerinde ayrımcılığa maruz kalan bir grup olarak karşımıza çıkmaktadır. "Engelli bireyler hemen hemen her ekonomik etkinlik göstergesinde engelli olmayan bireylerin gerisinde kalmaktadır” (aktaran Niles ve Harris-Bowlsbey, 2013, s. 147). Engelli öğrencilerin yükseköğrenimdeki paylarının da, sayıları artmakla birlikte, sayılarına oranla daha düşük olduğu bilinmektedir (Organisation for Economic Co-operation and Development [OECD], 2010).

"Amerikan Engelliler Derneği engelliliğin tanımını, fiziksel veya zihinsel farklılıkların bireyin, bir veya daha fazla yaşamsal aktivitesini (dil, hareket, öğrenme, bağımsız yaşam becerileri vb.) kısıtlaması şeklinde ifade etmiştir” (Hibbard ve Desch, 2007, s. 1019). Herr ve arkadaşları (2004), engelli bireyi kaza, hastalık, doğum ya da gelişim sorunları nedeniyle normal bireyden - fiziksel, fizyolojik, nörolojik ya da psikolojik olarak - farklı olan birey olarak tanımlar. Engelli Amerikalılar Yasası (1991) engelli bireyi, temel yaşam faaliyetlerinin birini ya da fazlasını önemli ölçüde sınırlayan fiziksel ya da zihinsel bozukluğu ya da bu tür bozukluk geçmişi olan ya da bu tür bir bozukluğu olduğu düşünülen kişi şeklinde tanımlar (aktaran Niles ve Harris-Bowlsbey, 2013, s. 148).

Engelliliğin anlamı, daha çok toplumdaki diğer insanların engelli bireye verdikleri tepkilerle ilgilidir. Bu tepkiler olumsuz olduğunda engelli bireyler toplum içerisinde çeşitli güçlüklerle karşılaşabilmektedirler. Örneğin, birçok ebeveyn, çocuklarının sınıfına engelli bir çocuğun dâhil edilmesinin, kendi çocuklarının öğrenme süreçlerini yavaşlattığını düşünmektedir (Moores, 2013). Doğuştan veya sonradan kazanılmış engelliliğin sosyal ve kültürel anlamı, bireyin engeline yönelik tepkileri ve toplumun engelli bireye bakış açısına göre şekillenir ki bu kültürel anlam, toplumdan topluma değişiklik gösterir (Burcu, 2002). Normal gelişim gösteren çocukların 
ailelerinin, öğretmen ve idarecilere baskı yaparak, engelli çocukların eğitim-öğretim süreçlerini olumsuz etkiledikleri gözlenebilmektedir.

Zunker (2006), engelli bireylerin genel olarak karşılaştıkları birkaç kariyer gelişimi sorununu tanımlar. Özellikle engellere uyum sağlamayla ilgili sorunların (bireyler fiziksel travma yaşadıklarında ve ardından engellerine uyum sağlama ve bunu kabul etmede zorluk çekmeleri gibi) yanlış bilgi ve ayrımcı düşünceler nedeniyle tutumsal engellerle karşılaşma, engelli ya da sakat olarak etiketlenmeleri sonucu meydana gelen genellemelerin üstesinden gelme, rol modellerinin ve norm gruplarının olmaması, engelin başladığı yaşa ilişkin sorunlarla başa çıkma, sosyal/kişiler arası beceriler geliştirme, olumlu bir benlik kavramı geliştirme ve bağımsız yaşama becerileri geliştirme gibi sorunlar olduğunu belirtir. Bu sorunların her biri, engelli bireylerin kariyer gelişimini kolaylaştırmak için belirli kariyer gelişimi müdahaleleri gerektirir (aktaran Niles ve Harris-Bowlsbey, 2013).

Meslek seçimi çocukluk döneminden başlayarak genellikle ergenliğin sonuna kadar şekillenen bir süreçtir. Bu süreçte bireyin yeteneği, ilgisi, değerleri, aldığı eğitim, aile ve çevresi, akademik başarısı, beklentileri, cinsiyeti, ailenin sosyo-ekonomik düzeyi, iş bulma olasıllğ̆ı, mesleğin güncel ve popüler olması gibi etmenler meslek seçimini etkiler. Engelli bireyler ise bu meslek seçimi sürecinde farklı ek problemlerle de karşı karşıya kalmaktadırlar. Bu problemler bireylerin fiziksel engellerine uygun meslek programlarının ve materyallerinin olmayışından kaynaklandığı gibi uygun olmayan fiziksel ortamlardan da kaynaklanabilmektedir.

Engelli bireylerin meslek seçimi üzerine yapılan bir araştırma, engelli bireylerin engeli olmayan bireylere kıyasla bir iş için aynı isteklilikte olduğunu göstermiştir. Ayrıca geçmiş iş deneyimleri, gelirin önemi ve mesleğin karakteristiği konusunda da benzer görüşleri olduğu bulunmuştur. Bunlara rağmen etkin iş arayışlarının daha az olma eğiliminde olduğu görülmüştür. Buradan hareketle engelli bireylerin iş bulma konusundaki iyimserlik seviyelerinin daha düşük olduğu anlaşılmaktadır. Araştırma engelli bireylerin istihdamının önündeki engellerin kaldırılmasının gerekliliğini bir kez daha vurgulamaktadır (Ali, Schur ve Blanck, 2011).

Fiziksel, zihinsel, ruhsal ve sosyal bakımdan belli bir oranda ve devamlı bir şekilde işlev kaybı veya aksaklığı yaşayan; normal hayattaki faaliyetlerini gerektirdiği şekilde gerçekleştiremeyen kişiler olarak, engelli olanların da normal vatandaşlar gibi iktisadi, sosyal ve kültürel faaliyetlerden faydalanması en doğal haklarıdır ve bu 'sosyal devlet' anlayışını taşıyan ülkelerin önemli ilkelerinden biri olmuştur (Ören, 2004). Engellilerin toplumsal yaşama tam katılımlarının sağlanmasına yönelik kamusal alanda iyileştirmelerin yapılması, onların çalışan, kazanan ve kendilerine yeten bireyler olmaları için desteklenmeleri toplumsal yaşamın bir gereğidir (Ylldırım vd., 2011).

Eğitim ve öğrenme insan hayatının her dönemini kapsamaktadır. Bu nedenle hayat boyu öğrenme; engelli olsun ya da olmasın kişilerin gerek topluma kazandırılmasında gerek tüketimden üretime geçmesinde en önemli etkenlerdendir. Engelli bireyin değişen ve çeşitlenen toplumsal rollere, ekonomik ve teknolojik gelişmelerin ortaya çıkardığı yeni gerekliliklere uyum sağlayabilmesi için hayat boyu devam eden bir süreçte eğitilmelerine ihtiyaç duyulmaktadır. 


\section{Araştırmanın amacı}

$\mathrm{Bu}$ araştırmada, üniversitede öğrenim gören veya üniversiteden mezun olmuş engelli bireylerin meslek seçimlerini etkileyen faktörlerin incelenmesi amaçlanmıştır. Bu amaca uygun olarak aşağıdaki sorulara cevap aranmaya çalışılmıştır:

1. Engelli bireylerin meslek seçiminde anne-babalar nasıl tutum takınmaktadırlar?

2. Engelli bireylerin meslek seçiminde sosyal çevre nasıl bir rol oynamaktadır?

3. Engelli bireylerin meslek seçiminde seçeceği üniversitenin fiziksel koşullarının nasıl bir rolü vardir?

4. Engelli bireylerin meslek seçiminde ailenin ekonomik düzeyinin rolü nasıldır?

5. Engelli bireylerin engel durumları meslek seçimini nasıl etkilemektedir?

6. Engelli bireyler ilgileri doğrultusunda mesleklerini seçebiliyorlar mı?, Engelli bireylerin bütün engelleri ortadan kalkarsa meslek seçimleri değişir mi?

7. Engelli bireylerin meslek seçimlerini etkileyen bu faktörlerin önem sıralaması nasıldır?

\section{Yöntem}

\section{Araştırmanın modeli}

Araştırmada, nitel araştırma yöntemlerinden "Olgubilim (fenomenoloji)" deseni kullanılmıştır. Nitel araştırma, "gözlem, görüşme ve doküman analizi gibi nitel veri toplama yöntemlerinin kullanıldığı, algıların ve olayların doğal ortamda gerçekçi ve bütüncül bir biçimde ortaya konmasına yönelik nitel bir sürecin izlendiği araştırma” türü olarak tanımlanabilir (Yıldırım ve Şimşek, 2013, s. 45). Nitel araştırmalar, kişilerin deneyimlerini, duygu ve düşüncelerini daha iyi anlayabilmek için tercih edilen araştırmalardır (Ekiz, 2009).

Olgubilim deseni farkında olduğumuz ancak derinlemesine ve ayrıntılı bir anlayışa sahip olmadığımız olgulara odaklanmaktadır. Olgular yaşadığımız dünyada olaylar, deneyimler, algılar, yönelimler, kavramlar ve durumlar gibi çeşitli biçimlerde karşımıza çıkabilmektedir. Ancak bu tanışıklık olguları tam olarak anladığımız manasına gelmez. Bize tümüyle yabancı olmayan, aynı zamanda da tam anlamını kavrayamadı̆̆ımız olguları araştırmayı amaçlayan çalışmalar için olgubilim uygun bir araştırma zeminini oluşturur (Yıldırım ve Şimşek, 2013). Gluck ve Patai'ye (1991) göre fenomenolojik çalışmalarda araştırmacının hedefi ve rolü katılımcıların deneyimlerini elde etmek ve onların gördügü gibi görebilmektir (aktaran Vanderstop ve Johnston, 2009). Araştırmacı katılımcının kişisel (öznel) tecrübeleri ile ilgilenmekte, bireyin algılamaları ve olaylara yükledikleri anlamları incelemektedir. Fenomenoloji tanımlayıcı bir araştırmadır. Bu bağlamda genelleme yapmak değil, olguları tanımlamak önemlidir (Akturan ve Esen, 2008).

$\mathrm{Bu}$ araştırmada, "engellilerde meslek seçimi” olgusu incelenmeye çalışılmıştır. Araştırma, konuya ilişkin ilgili literatürün taranması, görüşme sorularının oluşturulması, görüşmenin gerçekleştirilmesi ve verilerin değerlendirilmesi biçiminde yürütülmüştür. 


\section{Çalışma grubu}

Araştırma, çeşitli üniversitelerde öğrenim gören veya üniversitelerden mezun olmuş bireylerle yapılmıştır. Araştırmanın çalışma grubu, farklı bölümlerde (psikoloji, uluslararası ticaret, sosyoloji, sınıf öğretmenliği, bilgisayar mühendisliği, iletişim tasarımı, Türk dili ve edebiyatı, rehberlik ve psikolojik danışmanlık, Türkçe öğretmenliği, dış ticaret) öğrenim gören veya mezun olmuş 10 engelli bireyden oluşmaktadır.

$\mathrm{Bu}$ araştırmada olasılık temelli örnekleme yöntemlerinden "aşırı veya aykırı durum örnekleme yöntemi” kullanılmıştır. Bu yöntem, derin bir incelemeye tabi tutulabilecek sınırlı sayıda ancak aynı ölçüde de bilgi bakımından zengin durumların çalışılmasını öngörür (Yıldırım ve Şimşek, 2013). Aykırı durum örneklemesinde normal dışı veya bir biçimde özel alışılmadık durumlardan katılımcılar seçilir (Patton, 2002). Bu çalışmada, engelli bireylerin meslek seçimleri aykırı durum olarak ele alınmış ve bölüm tercihlerini yaparak üniversitede öğrenim gören veya üniversiteden mezun olmuş bireyler araştırmanın katılımcılarını oluşturmuştur. Katılımcılar gönüllülülk esasına göre araştırmada yer almışlardır. Araştırmaya katılan bireylerin demografik bilgileri Tablo 1'de sunulmuştur;

Tablo I

Katılıma Bilgileri

\begin{tabular}{|c|c|c|c|c|c|c|c|}
\hline Katılımcı & $\begin{array}{c}\text { Engel } \\
\text { durumu }\end{array}$ & Yaş & $\begin{array}{c}\text { Kardeş } \\
\text { sayısı }\end{array}$ & $\begin{array}{l}\text { Ailenin algilanan } \\
\text { ekonomik düzeyi }\end{array}$ & $\begin{array}{c}\text { Mezun olduğu } \\
\text { lise türü }\end{array}$ & Üniversitesi & $\begin{array}{c}\text { Annenin / Babanın } \\
\text { eğitim düzeyi }\end{array}$ \\
\hline $\begin{array}{c}\text { Katılımc1 } 1 \\
\text { (Kadın) }\end{array}$ & Bedensel & 21 & 2 & Orta & Devlet & Vakıf & Lise / İlkokul \\
\hline $\begin{array}{c}\text { Katılımci } 2 \\
\text { (Erkek) }\end{array}$ & Bedensel & 26 & 3 & İyi & Özel & Devlet & İlkokul / İlkokul \\
\hline $\begin{array}{c}\text { Katılımc1 } 3 \\
\text { (Kadın) }\end{array}$ & Bedensel & 20 & 2 & Çok iyi & Özel & Vakıf & $\begin{array}{c}\text { Üniversite / } \\
\text { Üniversite } \\
\end{array}$ \\
\hline $\begin{array}{c}\text { Katılımci } 4 \\
\text { (Erkek) }\end{array}$ & $\begin{array}{c}\text { Bedensel ve } \\
\text { Konuşma }\end{array}$ & 22 & 2 & Düşük & Devlet & Vakıf & Lise / Lise \\
\hline $\begin{array}{c}\text { Katılımc1 } 5 \\
\text { (Erkek) }\end{array}$ & Bedensel & 23 & 2 & Çok iyi & Açılk lise & Vakıf & Lise / Üniversite \\
\hline $\begin{array}{c}\text { Katılımc1 } 6 \\
\text { (Kadın) }\end{array}$ & Görme & 34 & 4 & Orta & Devlet & Devlet & $\begin{array}{c}\text { Ortaokul / } \\
\text { Ortaokul }\end{array}$ \\
\hline $\begin{array}{c}\text { Katılımc1 } 7 \\
\text { (Erkek) }\end{array}$ & Bedensel & 25 & 4 & Orta & Devlet & Devlet & İlköğretim / Lise \\
\hline $\begin{array}{c}\text { Katılımc1 } 8 \\
\text { (Kadın) }\end{array}$ & Bedensel & 36 & $\begin{array}{c}\text { Tek } \\
\text { çocuk }\end{array}$ & Orta & Devlet & Vakıf & Lise / Lise (vefat) \\
\hline $\begin{array}{c}\text { Katılımc1 } 9 \\
\text { (Erkek) }\end{array}$ & Görme & 26 & 2 & Orta & Devlet & Devlet & Lise / Üniversite \\
\hline $\begin{array}{c}\text { Katılımc1 } \\
10 \text { (Kadın) }\end{array}$ & Bedensel & 24 & 3 & Orta & Devlet & Vakıf & Lise / Lise (vefat) \\
\hline
\end{tabular}

Katılımcıların 5'i kadın (\% 50), 5’i erkektir (\% 50). Katılımcıların yaş ortalaması 25,7'dir. 7’si bedensel engelli, 2'si görme engelli, 1'i ise hem bedensel hem de konuşma güçlüğü yaşamaktadır. 


\section{Veri toplama araçları}

Araştırmada öğrencilere, demografik bilgilerin (cinsiyet, yaş, kardeş sayısı, anne babanın eğitim durumu, ailenin algılanan ekonomik düzeyi, engel durumu, mezun olunan lise türü ve üniversite) yanı sıra araştırmacı tarafından hazırlanan altı adet açık uçlu soru ve bir adet sıralama sorusu sorulmuştur.

Araştırmada iki ana tema ele alınmıştır; (1) Engelli bireylerin meslek seçiminde etkili olan faktörler; (2) Meslek seçiminde etkili olan bu faktörlerin önem sıralaması.

Bu iki ana temayla ilgili görüşme soruları aşağıda belirtilmiştir;

1. Okumak istediğinizde aileniz nasıl bir tutum sergiledi? Eğitim süreciniz boyunca anne ve babanız nasıl davrandı? Nasıl destek oldu? Kaygıları var mıydı? Süreci kısaca anlatabilir misiniz?

2. Lise son sınıfta meslek seçimine karar vermekte ne kadar zorlandınız? Tekerlekli sandalyeli olmak veya engeliniz sizi ne kadar kısıtladı? Bu süreçte çevrenizdeki insanlar sizi ne kadar yönlendirdi veya hayatınıza müdahale etti? Arkadaşlarınızın ya da çevrenizdeki insanların meslek seçiminizdeki etkisi nedir?

3. Gitmek istediğiniz üniversitenin fiziksel koşulları meslek seçiminizi nasıl etkiledi?

4. Sizce ailenizin ekonomik durumu meslek seçiminizde etkili oldu mu?

5. Engel durumunuz meslek seçiminde sizi ne kadar etkiledi?

6. İlgi alanlarınızdan veya hobilerinizden bahseder misiniz? Meslek seçiminizde bu ilgi alanlarının ne kadar etkisi oldu? Sihirli bir değnek olsa ve fiziksel engeliniz bir anda ortadan kalksa yine aynı mesleği yapar mısınız? Nedenini açıklar mısınız?

7. “Anne baba tutumu, sosyal çevrenin etkisi, kampüsün fiziksel durumu, ekonomik düzey, engel durumu ve ilgi alanı" maddelerini meslek seçiminizde en etkili olandan etkili olmayana doğru sıralayabilir misiniz? Sıralama nedenini açıklar mısınız?

Ayrıca doküman incelemesi yapılarak “engellilerde meslek seçimi” olgusuyla ilgili kayıt ve belgelere ulaşılmaya çalışılmış ve bu kaynaklar taranarak veriler toplanmıştır. Doküman analizi araştırılması hedeflenen olgu veya olgular hakkında bilgi içeren yazılı materyallerin analizini kapsamaktadır. Doküman analizi dokümanlara ulaşma, orijinalliğin kontrol edilmesi, dokümanların anlaşılması, verinin analiz edilmesi ve kullanılması olmak üzere beş aşamada gerçekleştirilmektedir (Yıldırım ve Şimşek, 2013). Bu bağlamda öncelikle engellilerle ilgili kurum ve kuruluşların web sayfalarına erişilmiştir. Erişilen bu sayfalarda engellilerin meslek seçimiyle ilgili verilere ulaşılmaya çalışılmıştır. Yüksek Öğretim Kurumu’nun internet sitesinden tez taraması yapılmış ve Türkiye’deki makaleler araştırılmıştır. Türkiye İstatistik Kurumu, Aile ve Sosyal Politikalar Bakanlığı gibi kurumların yayınladıkları raporlara ulaşılmıştır. Ayrıca Milli Eğitim Bakanlı̆̆ı’na bağlı liselerdeki Rehberlik Programları incelenmiştir. 


\section{Verilerin toplanması}

Araştırmanın verileri, Kasım-Aralık 2015 tarihinde, yarı-yapılandırılmış birebir görüşme yöntemi kullanılarak toplanmıştır. Veriler, araştırmacı tarafından hazırlanan altı açık uçlu soru ve bir sıralama sorusu ile elde edilmiştir. Soruların oluşturulmasından önce alan taraması yapılmış, daha sonra amaca hizmet edeceği düşünülen yedi soruya araştırmada yer verilmiştir. Geçerliliği sağlamak adına eğitim bilimleri alanında çalışan üç alan uzmanına bu sorular gösterilerek görüş ve önerileri alınmış ve sorulara son şekli verilmiştir. Görüşme soruları, uygulamadan önce eğitim fakültesinde öğrenim gören öğretmen adaylarına verilerek açık ve anlaşılır oldukları belirlenmiştir.

Görüşme araştırmacı tarafından yapılmış ve bu görüşme esnasında katılımcılara araştırmanın konusu hakkında bilgi verilmiştir. Katılımcıların kimlik bilgilerinin gizli tutulacağı ve soruları yaşantıları doğrultusunda samimi bir şekilde cevaplamaları istenmiştir. Görüşmeler yaklaşık olarak 45-60 dakika arasında gerçekleştirilmiştir.

\section{Verilerin analizi}

Verilerin analizinde betimsel analiz yaklaşımı uygulanmıştır. Bu yaklaşımda amaç görüşme ve gözlem sonucu elde edilen verilerin düzenlenmiş ve yorumlanmış bir şekilde okuyucuya sunulmasıdır. Veriler daha önceden belirlenmiş temalara göre sınıflandırılır, özetlenir ve yorumlanır. Bulgular arasında neden-sonuç ilişkisi kurulur ve gerekirse olgular arasında karşılaştırmalar yapılır. Bu analizde, görüşülen bireylerin görüşlerini çarpıcı bir biçimde yansıtmak amacıyla doğrudan alıntılara sık sık yer verilmektedir (Yıldırım ve Şimşek, 2013). Betimsel analizde farklı kişilerin aynı soru hakkında farklı düşüncelerinin görüşülenlerden elde edildiği tarzda aktarılır (Altunışık, Çoşkun, Yıldırım ve Bayraktaroğlu, 2010). Betimsel analiz dört aşamadan oluşur: a. Betimsel analiz için çerçeve oluşturma, b. Tematik çerçeveye göre verilerin işlenmesi, c. Bulguların tanımlanması, d. Bulguların yorumlanması (Yıldırım ve Şimşek, 2013). Bu araştırmada, elde edilen verilerle tematik bir çerçeve oluşturulmuştur. Engelli katılımcıların görüşlerini yansıtmak için de katılımcıların ifade ettiği cümlelerden doğrudan alıntılar yapılmıştır.

\section{Araştırmanın geçerliği ve güvenirliği}

Araştırmanın geçerlik ve güvenirliğini sağlamak amacıyla aşağıdaki işlemler gerçekleştirilmiştir.

Araştırmada iç geçerliği artırmak amacıyla görüşme soruları hazırlanırken ilgili alanyazın incelemesi yapılarak kuramsal bir çerçeve oluşturulmuştur. Araştırma konusu hakkında bilgiye sahip ve nitel araştırma yöntemleri ile ilgili uzmanlığa sahip kişilerden araştırmayı çeşitli boyutlarda incelemelerini istemek araştırmanın inandırıcılığı konusunda alınabilecek bir önlemdir (Yıldırım ve Şimşek, 2013). Bu sebeple, görüşme sorularının araştırılan olguyu ortaya koyup koyamayacağını saptamak için iki alan uzmanının görüşlerine başvurulmuş ve geribildirimler doğrultusunda sorulara nihai şekli verilmiştir. Ayrıca verilerin analiz sürecinde de bir başka uzmanın görüşlerine başvurulmuş, tutarlılıklar ve çelişkilere dayalı olarak 
temalar ortaya konmuş böylece araştırmanın geçerliği artırılmaya çalışılmıştır. Araştırmanın dış geçerliğini artırmak amacıyla araştırma sürecindeki tüm yapılanlar ayrıntılı bir şekilde açıklanmaya çalışılmıştır. Araştırmanın modeli, çalışma grubu, veri toplama araçları, veri toplama süreci, verilerin çözümlenmesi ve yorumlanması, bu bağlamda ayrıntılı bir biçimde tanımlanmıştır.

Araştırmada elde edilen bulgular değiştirilmeden doğrudan verilmeye çalışılarak, elde edilen verilerin analizinde faklı bir araştırmacının yardımı alınarak ve önceden oluşturulmuş kavramsal çerçeveye bağlı yapılan veri analiziyle araştırmanın iç güvenirliğini artırmak amaçlanmıştır. Creswell ve Miller’a (2000) göre bir araştırmada güvenirliği (inandırıcılık) sağlamanın yollarından birisi de araştırılan durumu, katılımcıları ve nitel araştırmanın temalarını ayrıntılı bir şekilde betimlemektir. Araştırmanın dış güvenirliğini artırmak amacıyla süreçte yapılanlar ayrıntılı bir biçimde tanımlamıştır.

\section{Bulgular}

Araştırmada ele alınan iki ana tema; engelli bireylerin meslek seçiminde etkili faktörler ve meslek seçiminde etkili olan bu faktörlerin derecelendirilmesidir. Bu ana temalar ışı̆̆ında ortaya çıkan bulgular ve sonuçlar bu bölümde sunulmuştur.

\section{Engelli bireylerin meslek seçiminde etkili olan faktörler ana temasına ilişkin bulgular \\ a. "Engelli bireylerin meslek seçiminde anne-babalar nasıl tutum takınmaktadırlar?" sorusuna yönelik bulgular}

Anne-baba tutumlarına yönelik bu soruya verilen cevaplar incelendiğinde katılımcılar en çok "desteklemek, güvenmek, umursamazlık, yardımcı olmak, inanmak, yönlendirici, teşvik etmek, istekli” kelimelerini kullanmışlardır. Bu cevaplara göre ortaya çıkan alt tema "Aile Desteği"dir.

Aşağıda katılımcıların verdikleri cevaplardan alıntılar sunulmuştur;

"Hiç sorun çıkarmadılar hep desteklediler ve yapabileceğime inandılar."

"Annem o yıl kendi imkânlarıyla bana okumayı ve temel matematik bilgileri öğretti. Bana bolca kitap alıyor, bilgi seviyemi artırmaya çalışıyordu."

"Babamın olumsuz etkisi oldu çünkü çok pasifti. 'Sen bilirsin' gibi beni desteklemeyecek bir tutum sergiliyordu. Hayallerimi düşünmüyor, desteklemiyor ve beni yönlendirmiyordu.”

"Onlar daha çok teşvik ediyordu beni. Hep destekliyorlard. 'Şunu yap, şöyle yap, böyle yap' diye yol gösteriyorlardi. Ve benden hep eminlerdi."

"Okula zaten hep annem gelip götürüyordu. Herhangi bir kaygı yaşamadık. Gönül rahatlı̆̆ıla devam ettirdiler. Ailem daha çok tıp ve psikoloji bölümünü istedi. Edebiyat isteyen bir tek bendim. Edebiyata yönlendiğimi görünce kıramadılar, dayatmadılar.” 
"Ailem her zaman benim arkamda durdu. Ailemin bütün fertleri, annem babam hatta amcamdan halama kadar beni sürekli destekledi ve yardımo oldular. Ailem konusunda hayatımda hiçbir problem yaşamadım. Yalnız puanım tutmasına rağmen şehir dışında okuyamadım. Ailecek oraya taşınamayacağımız için bende bundan ötürü üstelemedim. İlkokulda annem sürekli yanımdaydı küçüklüğümde ama şu an daha bağımsızım"

"Özellikle ailem okumam konusunda çok istekliydi."

"Ailemi kaybettiğim için bu dönemde seçimimi kendim yaptım."

Sosyal destek, bireyin çevresinden gördüğü dürüst ve empatik tepki, ilgi, sevgi, güven, saygi, takdir edilme, bilgi edinme ve maddi yardım gibi kişisel, sosyal, psikolojik ve ekonomik nitelikli her türlü yardım olarak tanımlanmaktadır (Yıldırım, 2006). Ailedeki iletişim ve bağlılık, aile bireylerinin birbirlerine sundukları destek bireylerin sorunlarla başa çıkmasını, kendisini yalnız, çaresiz, dışlanmış hissetmemesini, olayları farklı algılayarak stres yaratan faktörler karşısında daha az etkilenmesini sağlayacaktır. Bireye sağlanan sosyal desteğin, bireyi olumsuz şartlar karşısında tampon gibi koruyacağı bilinmektedir.

\section{b. “Engelli bireylerin meslek seçiminde sosyal çevre nasıl bir rol oynamaktadır?" sorusuna yönelik bulgular}

Sosyal çevre etkisine yönelik bu soruya verilen cevaplar incelendiğinde katılımcilar en çok "Rol Model, Değer verme, Teşvik etme, Yardımcı olmak, Rol model, Öğretmen, Müdahale, Yardımsever, Destek olmak, Yönlendirmek" kelimelerini kullanmışlardır. Bu cevaplara göre ortaya çıkan alt tema "Rol Model"dir.

Aşağıda katılımcıların verdikleri cevaplardan alıntılar sunulmuştur;

"Belki karar vermemde etkili olan iki figür sayabilirim; birincisi danışmanlık yapan psikolog rol model oldu, ikincisi de dershanede tercihlerimde bana yardimcı olan hocam."

"Lisedeki arkadaşlarım bana yardımcı oldu."

"Lisedeki hocalarım bana çok destek oldu. Bu süreçte benimle ilgilendiler ve benim için araştırmalar yaparak bana seçenekler sunup her ihtimali değerlendirmeye çalı̧stllar. Olumsuz olan ise ilkokulda müdürün şahsi düşüncesi sebebi ile beni okula almayarak hayatıma kötü bir müdahalede bulunmasıydı"

"Lisede edebiyat öğretmenim çok yardımcı oldu. Sürekli bunu yapabilirsin diye seçenek sunuyordu. Başkasının iş yerinde çalışmayı sevmiyorum. O bunları ortaya çıkardı. Tercih yaparken ve okul seçerken yardimci oldular."

"Bana kitap okuyan ve ders çalışmama yardımcı olan arkadaşlarımın desteği çok oldu ama dalga geçen ve kabullenemeyen arkadaşlarımla da çok sıkıntı yaşadım"

"Edebiyat hocalarım yönlendirdi. Edebiyat hocalarımı daha çok seviyordum. Arkadaşlarımın pek etkisi olmadı bu konuda çünkü meslek seçimi için arkadaşlarımla bir araya gelmedim." 
"Ailem ve öğretmenlerim felsefe öğretmenim özellikle etkiledi."

"Üniversitedeyken hocalarım "sen şu mesleği şu sebeple de yapabilirsin, engellilik burada sana engel değildir bu meslekte" diye beni yönlendirdiler. Genelde çevremdeki insanların hep olumlu etkisi olmuştur. Benim kendi karakterimde hep olumluluk üzerinedir. Arkadaş çevremde benim gibi bir düşünce yapısına sahip oldukları için güzel bir ilerleme kaydettim."

Rol model; kişinin hedeflerini, tutumlarını ya da davranışlarını örnek aldığı, özdeşim kuruduğu ve taklit etmeye çalıştığı insanlar ya da gruplar (Budak, 2003) olarak tanımlanmaktadır. Engelli bireylerin aile, arkadaş, öğretmen gibi güçlü rol modeller aracılığıyla hayatlarını biçimlendirdikleri, kendilerine ilham kaynağı oldukları, meslek seçerken kendilerine yardımcı oldukları görülmektedir.

\section{c. “Engelli bireylerin meslek seçiminde seçeceği üniversitenin fiziksel koşullarının nasıl bir rolü vardır?" sorusuna yönelik bulgular}

Üniversitenin fiziksel durumuna yönelik bu soruya verilen cevaplar incelendiğinde katılımcılar en çok "Amfi sistemi, Kütüphane, Asansör, Kaldırımlar, Servis, Derslik, Asansör” kelimelerini kullanmışlardır. Bu cevaplara göre ortaya çıkan alt tema "Engelli dostu yapılar"dır.

Aşağıda katılımcıların verdikleri cevaplardan alıntılar sunulmuştur;

"Okuldaki kütüphane, kantin, wc gibi yerleri rahatlikla kullanabiliyorum."

"Sınıfta amfi sistemi olduğu için ders esnasında zorluk yaşamaktayım."

"Servislerde ise engellilere uygun shuttle'larımız (iki yer arasında sürekli sefer yapan servis aracı) sadece iki tane. O yüzden o konuda bazen sıkıntı çıkabiliyor.”

"Üniversite seçimlerinde fiziki koşullar sebebiyle vakıf üniversitesini tercih ettim. Benim dönemimde devlet üniversitesinde okuma şansım yoktu. Bir vakıf üniversitesinde burslu okudum. Buranın fiziki koşulları devam etmemde ve karar vermemde etkili oldu.”

"Sonuçta engelime göre yer seçmem gerekiyor. Engelim olduğu için fiziksel koşullara dikkat ediyorum. Engelli olmasam bunlar ortadan kalkacaktı, kısıtlı olmayacaktı."

"Dersliklerdeki sandalyelere oturamiyorum."

"Üniversitenin fiziki ortamı fazla zorlamıyor."

"Kollarımda da engel olduğu için kapı açmakta ve asansör kullanmakta zorlanıyorum."

Fiziksel koşulların engelli bireylerin kullanımlarına uygun hale getirilmesinin günlük yaşam için gerekliliği dikkate çarpmaktadır. Lavabo, tuvalet, merdiven, bina girişleri, kaldırım, asansör, toplu taşıma araçları vb. günlük yaşamda kullandığımız araç ve mekanların engellilere göre tasarlanmaması eşitlik ilkesini bozmakta ve engelli bireyleri dezavantajlı duruma düşürmektedir. 


\section{d. "Engelli bireylerin meslek seçiminde ailenin ekonomik düzeyinin rolü nasıldır?" sorusuna yönelik bulgular}

Ekonomik düzeye yönelik bu soruya verilen cevaplar incelendiğinde katılımcılar en çok “Maddi sıkıntı, İmkânlar, Özel ders, Avantaj, Özel okul” kelimelerini kullanmışlardır. Bu cevaplara göre ortaya çıkan alt tema "Maddi imkânlar"dır.

Aşağıda katılımcıların verdikleri cevaplardan alıntılar sunulmuştur;

"Maddi açıdan hiç sorun yaşamadım. Okulu bitirince kendi fabrikamızda çalışacağım bu yüzden daha rahattım."

"Babamın vefat etmesiyle birlikte annem maddi açıdan zorlandı bu yüzden imkânlarım kısıtlıyd. Burs alıyordum ve çevremiz destek sağhyordu. Okulu tam burslu kazanmamla birlikte imkânlarım çoğaldı.”

"Maddi durumumuzun iyi olması benim için avantajdı. Çünkü lisede örgün eğitim almadığım sırada özel dersler alıyordum.”

"Maddi imkânımız yeterli olduğu için özel üniversiteyi tercih ettim çünkü özel üniversitelerin engelliler için fiziksel koşulları daha iyi."

"Daha iyi ilgilenilmem için maddi durumumuzun iyi olmasıla birlikte ailem özel okulu tercih etti."

Engelli bireylerin, normal standartları sağlamak için ekstra harcama yapmak zorunda kalmaları, daha fazla maddi olanaklara sahip olması gerektiğini göstermektedir. Engellerinden kaynaklanan dezavantajları maddi olanaklarla kısmen de olsa kapatma imkanı bulunmaktadır.

\section{e. "Engelli bireylerin engel durumları meslek seçimini nasıl etkilemektedir?" sorusuna yönelik bulgular}

Engel durumuna yönelik bu soruya verilen cevaplar incelendiğinde katılımcılar en çok "Engel durumu, Hayaller, Örgün eğitim, Ergenlik, Materyal yetersizliği” kelimelerini kullanmışlardır. Bu cevaplara göre ortaya çıan alt tema "Engelleyen engeller"dir.

Aşağıda katılımcıların verdikleri cevaplardan alıntılar sunulmuştur;

"Engel durumum olduğu için meslek seçimimde bunu düşünerek hareket ettim."

"Lisedeyken engelim yoktu. 17 yaşımdayken 17 Ağustos Marmara depreminde gerçekleşti. Lise dönemimde daha farklı hayallerim vardı ama engelimden dolayı fikirlerim değişti.”

"Mesleği seçerken fiziksel durumumum pek olumsuz etkisi olmad. Bilakis masa başı diye daha rahat göründü. İlköğretimi bitirdikten sonra fiziksel durumumu iyiye götürmek için yoğun bir fizik tedavi programı uygulandı. Dört yıl boyunca her gün eve fizyoterapist geldi bu yüzden örgün eğitim alamadım.”

"Bayă̆ı sorunlar yaratan bir dönemdi. Hem duygusal hem de sosyal açıdan sosyalizasyon problemleri izole olmuş hissetme gibi bir de üstüne ergenlik gelince zorlandım.”

"Engelim nedeniyle yapabildiğim tek şey bilgisayarda yazı yazmaktı." 
"Sinıfta tek görme engelli bendim. Kitap okuma sıkıntım vardı. Sinavlarıma diğer arkadaşlarım gibi çalışamıyordum. Üniversitede hocalarımın verdiği kitaplar sesli ya da kabartmalı olmadı̆̆ı için sıkıntı yaşadım. Bu yüzden sınava düzgün hazırlanamadım."

"Engel durumumu göz önünde bulundurarak bir tercih yaptım. Çünkü başarılı olabileceğim bir alanda okumam gerekiyordu. Benim önümdeki engellileri dikkate alarak seçtim."

Engelli bireylerin meslek seçimi yaparken engel durumlarını dikkate aldıkları fakat engellerin bu bireylerin hayatını ciddi şekilde etkilediği, karşılarına birçok zorluk çıkarttığı, engellerinin hayatlarına zaman zaman engel olduğu görülmektedir.

\section{f. "Engelli bireyler ilgileri doğrultusunda mesleklerini seçebiliyorlar mı?, Engelli bireylerin bütün engelleri ortadan kalkarsa meslek seçimleri değişir mi?" sorularına yönelik bulgular}

İlgi alanlarına yönelik bu soruya verilen cevaplar incelendiğinde katılımcılar en çok "DJ'lik, Fotoğraf çekimi, Blogger, Tasarımlar, Resim kursu, Şiir, hikâye Yazmak, Politika, Kitap okumak" kelimelerini kullanmışlardır. Bu cevaplara göre ortaya çıkan alt tema "Aktif ilgi alanları"dır.

Aşağıda katılımcıların verdikleri cevaplardan alıntılar sunulmuştur;

"Belki DJ'lik eğitimi alırdım bir turntable’in başında olmayı çok isterdim. Kafamı boşaltırdı ve dinlendirirdi."

"Fotoğraf çekmek, gezmek, film izlemek. Görsel tarafını çok seviyorum. Sosyal medya aracılı̆̆ıyla dünya hakkında bilgi ediniyorum. Blogger kullanıyorum. Yurtdışına çıkmayı seviyorum.”

"Tasarımlara meraklyım. Atölyem olmasını isterdim. 10 yașıma kadar problemim yoktu. Resim kursuna gitmiştim resmim çok iyiydi. Sonra ellerime hareketsizlik gelince bırakmak zorunda kaldım. Devam ettirmek isterdim. Dil ögrenmek istiyorum."

"Şiir ve hikâye yazmak. Yapmak isteyip yapamadiğım bir hobim yok"

"Futbol, basketbol, tenis, yüzme hatta yüzmede madalyalarım var. Tarihle çok ilgiliyim. Satranca meraklyım ve politikayı çok seviyorum. Kitap okumaktan çok zevk alırı"

Mesleği isteyerek seçip seçmediklerine yönelik diğer soruya verilen cevaplar incelendiğinde ise ortaya çıkan alt tema "Meslek değişimi"dir. Aşağıda katılımcıların verdikleri cevaplardan alıntılar sunulmuştur;

"Zannediyorum ki yapardım. Meslek konusunda bir değişiklik olmazdı ama eğer yürüseydim özel zevklerimi daha rahat gerçekleştirebilirdim."

"Hiç kuşkusuz yine aynı mesleği yapardım."

"Yapmazdım çünkü yönelmelerim o doğrultuda olmayacaktt, hayattan başka şeyler isteyip başka şeyler bekleyeceğim kısacası tamamen değișecekti. Engelim ortadan kalktığında beni kısıtlayan koşulların olmaması hayallerimi ona göre değiştirirdi."

"Evet yapardım. Çünkü mesleğim benim ilgi alanımla alakalı." 
"Belki üniversitede asistanlı yapmazdım. Sanırım seyahat sitesi oluşturup sürekli gezip fotoğraflar çekerdim."

"Sanırım yine ayn mesleği yapardım çünkü büyük bir zevkle yapıyorum, mesleğimi seviyorum."

"Bu konu hakkında hiç düşünmemiştim. Farklı bir şey yapar mıydım bilmiyorum."

"Sanmam. Bölümümü seviyorum ama eğer başka bir meslek zorunda olsam ve bu mümkün olsa politikaya girmek isterdim."

Engelli bireylerin meslek tercihleri yaparken engel durumlarını göz önüne aldıkları, kendi gerçekliklerine göre hareket ettikleri görülmektedir. Engellerinin sosyal hayata katılmaya, üniversitede okumaya, hayallerini gerçekleştirmeye engel olmadığı, bununla birlikte engellerini kabul ederek gerçekçi kararlar almaya çalıştıkları tespit edilmiştir. Birçoğu mesleğini değiştirmeyeceği ve severek mesleklerini seçtikleri yönünde kanaat belirtmiştir.

2. Meslek seçiminde etkili olan faktörlerin önem sıralaması ana temasına yönelik bulgular

g. "Engelli bireylerin meslek seçimlerini etkileyen bu faktörlerin önem sıralaması nasıldır?" sorusuna yönelik bulgular

Tablo 2

Katilımciların Siralamaları

\begin{tabular}{cccccccccccc}
\hline Faktörler & K 1 & K 2 & K 3 & K 4 & K 5 & K 6 & K 7 & K 8 & K 9 & K 10 & Toplam \\
\hline Anne-baba tutumu & 3. & 4. & 5. & 4. & 5. & 5. & 5. & 5. & 6. & 4. & 24 \\
Sosyal çevre etkisi & 2. & 5. & 2. & 5. & 4. & 4. & 4. & 4. & 3. & 5. & 32 \\
Kampüsün fiziksel durumu & 4. & 6. & 4. & 2. & 6. & 3. & 6. & 1. & 4. & 6. & 28 \\
Ekonomik düzey & 6. & 3. & 6. & 3. & 3. & 6. & 3. & 6. & 2. & 2. & 30 \\
Engel durumu & 5. & 1. & 1. & 6. & 1. & 1. & 2. & 2. & 1. & 1. & 49 \\
İlgi alanı & 1. & 2. & 3. & 1. & 2. & 2. & 1. & 3. & 5. & 3. & 47 \\
\hline
\end{tabular}

Tablo 2'deki sıralamalar yapılırken; birinci tercihler 6, ikinci tercihler 5, üçüncü tercihler 4, dördüncü tercihler 3, beşinci tercihler 2, altıncı tercihler 1 şeklinde puanlandırılmış, daha sonra toplam puanlara göre önem sıralaması yapılmıştır. Sıralama aşağıda verilmiştir (Tablo 3);

Tablo 3

Meslek Seçimini Etkileyen Faktörlerin Önem Sırası

\begin{tabular}{ccc}
\hline Faktörler & Sıralama & Toplam Puan \\
\hline Engel durumu & 1. & 49 \\
İlgi alanı & 2. & 47 \\
Sosyal çevre etkisi & 3. & 32 \\
Ekonomik düzey & 4. & 30 \\
Kampüsün fiziksel durumu & 5. & 28 \\
Anne-baba tutumu & 6. & 24 \\
\hline
\end{tabular}


Tablo 3 incelendiğinde, engelli bireyler meslek seçimlerinde etkili olan faktörleri; engel durumu, ilgi alanı, sosyal çevre etkisi, ekonomik düzey, kampüsün fiziksel durumu, anne-baba tutumları şeklinde önem sırasına koymuşlardır.

\section{Sonuç, Tartışma ve Öneriler}

Engelli bireyler için sistematik bir mesleğe yönlendirme çalışmasının olmamasından ötürü engelli bireyler, kendi kendilerine girişim ve çalışma deneyimleri meydana getirmişler ve bireysel çabalarıyla bazı işlerde başarılı olmuşlardır. Engelli bireylerin iş yerinde başarılı olabilmesi için, işveren ve çalışanların mesleki, sosyal ve psikolojik açıdan eğitilmeleri ve fiziki/mimari şartların uygun hale getirilmesi gerekmektedir.

Engelli bireylerin engellerinden ötürü çalışma hayatına atılmada cesaretsiz olmaları, isteksiz davranmaları, yetersizlik duyguları ve bu sebeple geri planda kalmaları belli bir süre sonra toplumdan soyutlanmalarına neden olabilmektedir. Engelli bireylerin çalışma hayatına atılması ve sorumluluk alması, sadece ekonomik bağımsızlıklarını kazanmalarını değil, bunun yanı sıra sosyal ve psikolojik olarak da rehabilite olmalarını sağlamaktadır. Böylece engelli bireylerin başarılı olma, kendine güven duyma, başkaları tarafından onaylanma ve beğenilme gereksinimlerinin doyurulması, sosyal yaşamın içinde sadece tüketen değil aynı zamanda üreten de olabileceklerinin vurgulanması ve ekonomik kazançla birlikte gerekli ihtiyaçlarının karşılanamamasından kaynaklı özel sorunlarının da çözülmesi sağlanacaktır.

Engelli bireylerin özellik ve nitelikleri dikkate alınarak meslek seçimi konusunda yapılan çok kısıtlı sayıda araştırma bulunmaktadır. Bu araştırmada ise üniversitede öğrenim gören veya üniversiteden mezun olmuş engelli bireylerin meslek seçimlerini etkileyen bazı faktörlerin (engel durumu, anne-baba tutumları, sosyal çevre, kampüsün fiziksel yapısı, ekonomik düzey, ilgi alanı) incelenmesi amaçlanmıştır. Araştırma sonucunda engelli bireylerin meslek seçiminde etkili olan bu faktörleri sırasıyla engel durumu, ilgi alanı, sosyal çevre etkisi, ekonomik düzey, kampüsün fiziksel durumu ve anne-baba tutumları şeklinde ifade ettikleri tespit edilmiştir. Engeli bulunmayan bireylerin dahi üniversite ve meslek seçimi sürecinde ne kadar zorlandıkları bilinmekteyken, engelli bireylerin bu zorluğu diğerlerinden çok daha fazla yaşadıklarına bu araştırmada şahit olunmuştur.

Meslek seçiminde pek de dikkate alınmayan faktörler, engelli bireyler açısından tercih etme/ etmeme sebebi olabilmektedir. Örneğin; engeli olmayan bireylerde kampüsün fiziksel durumu sadece estetik bir anlam ifade ederken, bu faktör engelli bireylerde yaşam alanlarında mücadele etmeleri gereken zorluklar olarak algılanmaktadır.

Engelli bireylerden meslek seçimlerini etkileyen faktörleri önemine göre siralamaları istendiğinde ilk sırayı alan faktörün engel durumu olduğu görülmektedir. Engel durumunun meslek seçiminde ilk sırada çıkması en doğal sonuç olarak karşımıza çıkmaktadır. Birey bütün hayatını birçok açıdan engeline göre yeniden oluşturmak zorunda kalmaktadır. 
Birey engelinden dolayı maalesef kistllanmakta ve yapabileceği meslekler konusunda bir sınırlama gelmektedir. Bazı mesleklerde görme, işitme vb. sağlık problemlerinin olmaması istenirken bazı mesleklerde ise sağlık durumunun oluşturduğu engellilik pozisyonu bu mesleği yapmasına mani olmayabilmektedir. Örneğin; görme engelli bir bireyin fotoğrafçı olması ya da konuşma problemi olan bir bireyin turist rehberi olması pek de mümkün değildir. Bu sebeple engelli bireyler meslek seçimine öncelikle engeli doğrultusunda kararlar vermektedir.

Bireyde ve toplumda bir engelin diğer bütün gelişim alanlarında başarısızlığa yol açacağı algısı oluşmaktadır. Örneğin; fiziksel engelli bireyin bilişsel alanda da başarısız olacağı kanaati oluşmaktadır. Halbuki fiziksel engeli olan birisi bilişsel alanda harikalar yaratabilir. Bunun dünyadaki en bariz ve tanınan örneği olarakStephen Hawking verilebilir. Veya işitme engelli bir kişi, telefon operatörlügü yapması çok zor hatta mümkün değilken, fevkalade bilgisayar operatörlüğü yapabilmektedir. Engel durumlarına göre bireylere hizmet desteğinin çeşitlendirilerek verilmesi gerekmektedir. Örneğin; görme engelliler için sesli kütüphane, kabartma yazılı ders kitapları, vb.

Engelli bireylerin meslek seçimlerini etkileyen ikinci sıradaki faktör olarak ilgi alanının gelmesi aslında engelli bireylerin zorlama seçimlerden ziyade kendi istek ve yönelimlerine göre hareket ettiklerini göstermektedir. Engelli bireylerin almış oldukları eğitim doğrultusunda kendi ilgi ve yeteneklerine uygun bir mesleğe sahip olmaları benlik bütünlüğü ve en önemlisi hayata tutunabilme açısından son derece önemlidir (Law, 2002). Görüşmelerde "Engeliniz ortadan kalksa yine aynı mesleği yapar mıydınız?" sorusuna hemen hemen hepsi "evet" cevabını vermiştir. Bu sonuç da bizlere engelli bireylerin mesleklerini seçerken engellerini göz önünde bulundurduklarını ama ilgilerini de göz ardı etmediklerini göstermektedir. Buradan hareketle engelli bireyler adına konuşarak "şu engel grubu şu işi yapabilir, bu engeli grubu sadece bunu becerebilir" şeklinde önyargılarla hareket ederek engelin birey kişiliğinin ve becerisinin önüne geçmesine izin verilmemeli ve ayrımcıllğa düşülmemelidir. Bu bakış açısı engelli bireylerin iş alanlarında yanlış istihdamlarına sebep olmaktadır. İstisnalar dışında engellilere uygun meslek tanımı yapmak doğru olmamaktadır. Her birey biriciktir ve özeldir, ilgi ve yetenekleri doğrultusunda mesleklerini seçebilir ve devam ettirebilir. Bu noktada ekonomik düzeyin etkisini göz ardı etmemek gerekir, benzer bir çalışmanın farklı ekonomik düzeylerde de yapılması gerekli kılmaktadır. Engelli bireylerin ilgi alanlarını keşfetmeleri veya bu alanları geliştirmeleri adına özel kurslar açılabileceği gibi normal kurslara engellilere uygun düzenekler kurularak adapte edilebilir.

Üçüncü sırada ise sosyal çevrenin etkisi görülmektedir. Engelli bireyler doğal kabul görmekte zorlandıklarından ötürü evlerine kapanma eğilimi (sosyal izolasyon) ile karşı karşıya kalmaktadırlar. Evlerde ise onları daha çok koruma-kollama içgüdüsüyle hareket ederek, zarar görmemeleri için dışa açılmalarına engel olan ebeveyne karşılaşmaktadırlar. Engellilerin kendilerine örnek olacak başarılı rol modellere, kendileri gibi yaşam sürenlere, zorlukları aşanlara yani farklı bir ifadeyle onlar gibi damdan düşenlere ihtiyaç duymaktadırlar. Ayrıca diğer insanlarla iletişime geçip kabul görme, onaylanma, desteklenme, normal karşılanma ihtiyaçları vardır. $\mathrm{Bu}$ sebeple engellilerle normal bireyleri buluşturup kaynaştıracak mekânlara ihtiyaç bulunmaktadır. 
Meslek seçiminde ekonomik düzey dördüncü sırada gelmektedir. Ekonomik düzey engelli bireylerde bir kat daha önem arz etmektedir. Engelli bireylerin ekstra masrafları (fizik tedavi, özel eğitim, materyal, vb.) normal bireye göre daha fazladır. Ör: toplu taşıma araçlarını kullanamama sebebiyle taksi, özel araç veya belediyeden yardım alma zorunluluğunda kalma gibi. Böyle bir durum da ekonomik açıdan yeterli düzeyde olmayı gerektirmektedir. Devlet her ne kadar engelli bireylere maaş verse de yapılan görüşmelerde bu maaşın yeterli olmadığı görülmektedir. Vakıf üniversiteleri ve özel eğitim kurumları öğrenim burslarıyla bu öğrencileri destekleyebilirler.

Kampüsün fiziksel koşulları beşinci sırada yer almaktadır. Engelli bireylerin fiziksel koşulları önemseyip etkilenmelerine rağmen fiziksel koşulların son sıralarda çımasının aslında ekonomik düzeyle ilgili olduğu düşünülmektedir. Çünkü yapılan görüşmelerde bireyler mesleklerini üniversite bölümlerini seçerek yapmaktadırlar. Maddi açıdan iyi olan veya burs kazanan bireyler fiziksel koşullarının iyi olması sebebiyle daha çok vakıf üniversitelerini tercih etmektedirler, bu da meslek seçimini etkilemesi açısından son sıralarda yer almaktadır. Sadece üniversite kampüslerini değil, anaokulundan üniversiteye tüm eğitim-öğretim kademelerindeki kurumların tüm engel gruplarını kapsayacak şekilde engelli dostu bir mimariye sahip olmaları gerekmektedir.

Son sırada anne-baba tutumları yer almaktadır. Anne-babalar engelli çocukları için kaygı duymakla birlikte destekleyici ve yönlendirici konumda bulunmaktadırlar. Çocuklarını maddi ve manevi açıdan teşvik ederek meslek edinmelerinde etkili olmaktadırlar. Destekleyici annebaba tutumlarının çocukları ve gençleri geliştirdiği bilinmektedir. Zaten diğer yaşıtlarından dezavantajlı olan bu gençlere daha çok destek vermeli, güvendiğimizi göstermeli, kendi ayakları üzerinde bağımsız bir şekilde durabilmeleri için teşvik edilmelidir. Engelli olmak kadar engelli ebeveyni olmak da zordur. Çocukları kadar ebeveynlerin de destek mekanizmalarına ihtiyaçları vardır. Ebeveynler için destek yaşantı grupları, bireysel psikolojik danışma hizmetleri, eğitim merkezleri sağlanabilir.

Araştırmada elde edilen bulgular doğrultusunda ayrıca şu önerilerde bulunulabilir:

Anne babaların konu hakkında bilinçlendirilmesi gerekir. Belediyeler bu konuda eğitim ve seminerler düzenlemelidir. Fakat bu programa sadece engelli çocuğu olan anne babalar dışında diğer veliler de katılmalıdır çünkü engelli olmak sadece doğuştan olmayabilir.

Görme engelliler de (herkes gibi) bir işi yapabilir hale gelmek için eğitime ihtiyaç duyarlar. Onların eğitim ortamı ve materyalleri görme engellilerin erişebileceği duruma uygun hale getirilmelidir. Çünkü farklı eğitim materyallerine ihtiyaç duyduğu durumlar olabilir. Örneğin, dokümanların Braille alfabesiyle yazılması ya da seslendirilip, dinlenir hale getirilmesi gerekebilir. Görme engelli bireyin bilgisayar kullanmasını sağlayan yazılım ya da donanımlar olabilir.

Engellilerde eğitim özgün olmalıdır ve oluşacak ihtiyaca göre düzenlenmelidir. Engellilerin yeteneklerine, özür durumlarına uygun eğitim programları belirlenmelidir. Özründen dolayı temel eğitim alamayanlar ve örgün eğitime devam edemeyenler için yaş sınırlaması olmamalıdır.

Engelli bireyler eğitim gördükleri sırada arkadaşları ve sosyal çevreleri tarafından ötekileştirmeye maruz kaldıkları için psikolojik çöküntü yaşamaktadırlar. Bu yüzden okul öncesi 
dönemden başlanarak tüm kademelerde öğrencileri bilgilendirecek etkinlikler düzenlenmelidir. Engelli eğitiminin her bölgede uygulanabilmesi için mutlaka kamu ile sivil toplum kuruluşları işbirliğine başvurulmalı ve ortak yürütülmelidir.

Engelli bireylerin karşılaştığı güçlükler nedeniyle uygun mesleğe yönelme konusunda, hangi eğitim kademesinde olursa olsun, okuldan işe geçişte, engeli ve özelliklerine uygun bir işe yerleşmeleri ve bu işte en yüksek potansiyele ulaşabilmeleri için bu bireylerin mesleki rehberlik ve mesleğe hazırlama programı ile bazı temel gerekleri yerine getirmelidir.

Engelli bireylerin akranlarıyla birlikte ilerlemeleri için doğru zamanda desteklenmeleri ve yönlendirilmeleri gerekmektedir. Öğrenim kurumlarına devam eden çocuklara yetersiz olduğu alanlarda destek ve eğitim verilmeli ve bu öğrencilerin başarıları izlenerek özel olarak değerlendirilmelidir. 


\section{Kaynaklar}

Akturan, U. ve Esen, A. (2008). Fenomenoloji. T. Baş ve U. Akturan (Ed.), Nitel araştırma yöntemleri içinde, (s. 83-98). Ankara: Seçkin Yayıncılık.

Ali, M., Schur, L., \& Blanck, P. (2011). What types of jobs do people with disabilities want? Journal of Occupational Rehabilitation, 21(2), 199-210, doi: 10.1007/s10926-010-9266-0.

Altunışık, R., Çoşkun, R., Yıldırım, E. ve Bayraktaroğlu, S. (2010). Sosyal bilimlerde araştırma yöntemleri. Sakarya: Sakarya Kitabevi.

Arsoy, S. (2010). Mesleki rehberlik. E. İşmen Gazioğlu ve Ş. Mertol İlgar (Ed.), Öğretmen ve öğretmen adayları için rehberlik içinde (s. 169-204). Ankara: Pegem Akademi.

Budak, S. (2003). Psikoloji sözlüğü. Ankara: Bilim ve Sanat Yayınları.

Burcu, E. (2002). Üniversitede okuyan özürlü öğrencilerin sorunları: Hacettepe-Beytepe Kampüsü öğrencileri örneği. Hacettepe Üniversitesi Edebiyat Fakültesi Dergisi, 19(1), 83-103. http://www. engelsiz.hacettepe.edu.tr/belge/EsraBurcu1.pdf adresinden alınmıştır.

Creswell, J. W. ve Miller, D. L. (2000). Determining validity in qualitative inquiry. Theory Into Practice, 39(3), 124-130, doi.org/10.1207/s15430421tip3903_2.

Çoban, A. (2005). Lise son sınıf öğrencilerinin mesleki olgunluk düzeylerinin yordayıcı bazı değişkenlere göre incelenmesi. İnönü Üniversitesi Eğitim Fakültesi Dergisi, 6(10), 39-54. https://www.pegem. net/Akademi/3-8279-Lise-Son-Sinif-Ogrencilerinin-Mesleki-Olgunluk-Duzeylerinin-YordayiciBazi-Degiskenlere-Gore-Incelenmesi.aspx adresinden alınmıştır.

Ekiz, D. (2009). Bilimsel araştırma yöntemleri. Ankara: Anı Yayıncılık.

Hibbard, R. A., \& Desch, L. W. (2007). Maltreatment of children with disabilities. Pediatrics, 119(5), 10181025, doi: 10.1542/peds.2007-0565.

Kuzgun, Y. (2011). Meslek rehberliği ve danışmanlı̆̆ına giriş. Ankara: Nobel Yayınevi.

Law, M. (2002). Participation in the occupations of everyday life. The American journal of occupational therapy, 56, 640-649, doi:10.5014/ajot.56.6.640.

Moores, D. F. (2013). One size does not fit all: Individualized instruction in a standardized educational system. American Annals of The Deaf, 158(1), 98-103. http://gupress.gallaudet.edu/annals/13volume.htm adresinden alınmıştır.

Niles, S. G., Harris-Bowlsbey, J. (2013). 21. yüzyılda kariyer gelişimi müdahaleleri. F. Korkut Owen (Ed.), Ankara: Nobel Yayınevi.

OECD (Organization for Economic Cooperation and Development) (2010). Pathways for Disabled Students to Tertiary Education and Employment. http://www.oecd.org/edu/innovationeducation/47469308.pdf. Erişim Tarihi: 07.06.2016.

Ören, K. (2004). Zihinsel engellilerin istihdam sorunu ve dengeleyici tedbirler. Mali Çözüm Dergisi, Sayı 65, 126-139. https://issuu.com/istanbulsmmmodasi/docs/malicozum65?e=25078185/ 58370305 adresinden alınmıştır.

Patton, M. Q. (2002). Qualitative research \& evaluation methods (3rd Ed.). Thousand Oask, CA: Sage.

Super, D. E. (1957). The psychology of careers. New York: Harpers.

Tokar, D. M., Fisher, A. R., Subich, L. M. (1998). Personality and Vocational Behavior: A Selective Review of the Literature 1993-1997. Journal of Vocational Behavior, 53-115. https://www.academia.edu/857953/ Personality_and_vocational_behavior_A_selective_review_of_the_literature_1993_-1997 adresinden alınmıştır.

Türkiye İstatistik Kurumu Özürlülerin Sorunları ve Beklentileri Araştırması 2010. (2011) Yayın No: 3636, Kasım 2011, Ankara. www.tuik.gov.tr/IcerikGetir.do?istab_id adresinden edinilmiştir. 
Vanderstop, S. W. \& Johnston, D. D. (2009). Research methods for everylife: Blending qualitative and quantitative approach. San Francisco: Jossey-Bass.

WHO (World Health Organization) (2011). World Report on Disability. http://www.who.int/disabilities/ world_report/2011/report.pdf. Erişim Tarihi: 18.05.2016.

World Bank (2015). Overview. http://www.worldbank.org/en/topic/disability/overview. Erişim Tarihi: 19.05.2016.

Yeşilyaprak, B. (2013). 21. yüzyılda eğitimde rehberlik hizmetleri. Ankara: Nobel Yayınevi.

Yıldırım, İ. (2006). Anne baba desteği ve başarı. Ankara: Anı Yayıncılık.

Yıldırım, F., Dökmen, Z., Mamatoğlu, N., Özuğurlu, M., Karabulut, E. ve diğ. (2011). İsgü̈ü piyasasının özürlüler açısından analizi. Aile ve Sosyal Politikalar Bakanlığ Özürlü ve Yaşlı Hizmetleri Genel Müdürlüğü Yayınları, Ankara, http://eyh.aile.gov.tr/data /5458c557369dc34c643cef43/isgucu_ engelliler_tam_metin.pdf adresinden edinilmiştir.

Yıldırım, A. ve Şimşek, H. (2013). Sosyal bilimlerde nitel araştırma yöntemleri. Ankara: Seçkin Yayıncılık. 